\title{
BREAKING DOWN BARRIERS TO EFFECTIVE EFL COMMUNICATION: A LOOK AT SENSE-MAKING TECHNIQUES
}

Dr. Elena Stakanova, Southern Federal University, Rostov-on-Don, Russian Federation

E-mail: sevicanna@gmail.com

\section{ART I C LE INFO}

Original Research

Received: August, 06.2018.

Revised: October, 14.2018.

Accepted: November, 02.2018 .

doi:10.5937/ijcrsee $1803029 \mathrm{~S}$

UDK

$378.147:: 811.111(470)$

\section{Keywords:}

sense-making techniques,

motivation,

language barriers,

English as a foreign language,

meaning-centered instruction.

\begin{abstract}
A B S T R A C T
The present "new wave" investigation tackles cutting-edge perspectives of one of the most pressing problems - breaking down the barriers to effective fluent English communication. The publication reflects a broad array of studies in the area of methodology of teaching English. The investigation distills the research about sense-making techniques in the language awareness. The paper reveals obstacles and reasons for language barriers to fluent English communication. The author demonstrates an alternative way of approaching the problem of English as a foreign language acquisition. We undertake the empirical investigation of how foreign languages are learnt and taught using sense-making techniques. A foreign language should become a personal need for students allowing them to set goals, choose language improvement strategies, and exercise self-esteem and self-control. Against the backdrops of research, the experiment was carried out. Those tested were 85 students of Southern Federal University, Russia. They were split into two groups: a control group of tertiary participants who were given an instruction using traditional methods of teaching English; and a second group -experimental one implementing sense-making techniques in learning a target language.
\end{abstract}

(c) 2018 IJCRSEE. All rights reserved.

\section{INTRODUCTION}

Learning a foreign language is an everlasting and complex activity. To probe deep into the matter, motivation stems from accomplishments throughout life and success. "With a keen eye for achievement, admiring eye for efforts and a tolerant eye for differences and individuality, a skillful teacher can manage to enable the majority of his students to enjoy learning" (Fengying, 2003).

We are not always conscious about the fact that there are more than language structures, grammar, and lexis that we have to impart to our students. Pupils should not merely learn to imitate and reproduce speech patterns or memorize a grammar rule but explore a new

\footnotetext{
Corresponding Author

Dr. Elena Stakanova, Southern Federal University,

Rostov-on-Don, Russian Federation

E-mail: sevicanna@gmail.com
}

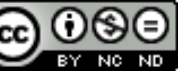

This work is licensed under a Creative Commons Attribution - NonCommercial - NoDerivs 4.0. The article is published with Open Access at www.ijcrsee.com way of self-expression and acquire language awareness (Gracheva, 2015). This concept dates back to the times of Charles the Great who claimed that "to have another language is to possess a second soul".

The bedrock goal of learning English is effective communication. Language awareness and ability to communicate are different things. Even good knowledge of English can be useless once an individual doesn't exploit it. The problem lies in the psychological barrier of making mistakes. Teachers are the greatest mistake hunters and fighters (Stepichev, 2009). Teachers should not act as mentors who are good at finding mistakes of students. If the teachers always find faults with students in terms of proper grammar or pronunciation, learners can be very demotivated and become scared to speak (Alam, et al 2018). Educators should indicate the learners' errors positively and with fun (Baker and Westrup, 2003). Pedantic teaching merely restricts learners to put their opinion freely and encumbers to produce communication in the class (Alam, et al 2018). "The decisions that the teachers make about how to react to students' performance will depend on the stages of the lesson, the activities, 
the types of mistake made, and the particular student who is making that mistake. Once the teachers correct whenever there is a problem, the conversation as well as the aim of the speaking activity will be ruined" (Harmer, 1983).

With the above in place, learners are afraid of making mistakes, experimenting, expressing original ideas. The greatest mistake you can make in life is to continually fear you will make one. Every mistake is a learning experience. A teacher's job is to nurture the environment where making mistakes is accepted as an integral part of learning (Beere, 2016).

Another obstacle is listening anxiety, depicted by Baran-Lucarz (2013) who endeavors to demonstrate that listening comprehension is a heavy barrier that prevents from perceiving effective language skills, and simultaneously declines students' speech production.

Throughout the language learning process, students inevitably face imperfection in their practice. By means of sense-making techniques of learning English teachers may raise students' motivation of the target language. EFL trainees lack the opportunities to practice English language skills with native speakers or be involved in the English environment outside the classroom (Amirian and Komesh, 2018). In other words, there is no English environment in Russia to practice English with the native speakers on a regular basis. The problem arises is how to enhance motivation of EFL learners.

What is motivation? Why do some people seem to be more motivated than others? There is the saying that "unmotivated students just will not learn". Students' success in the language awareness is contingent on versatile criteria. Be that as it may, the English language should become a personal need in the meaning-centered instruction. There are two types of motivation mentioned by Gardner: extrinsic and intrinsic (Gardner and MacIntyre, 1991). Extrinsic motivation revolves around the need to achieve a practical goal, travelling, getting a better job. Intrinsic motivation is akin to the inner motives to become familiar with culture of the target language. The scholars were not monolithic in their theoretical stances.

Dörnyei and Csizer (1998) proposed a raft of recommendations to augment motivation, such as aim-mindedness. Educators should help their trainees to cultivate language skills. In this connection, Krieger (2005), Alam, et al 2018. observe, "EFL students who lack intrinsic motivation may have high-extrinsic motivation if their education system emphasizes the extrinsic rewards flowing from high scores. Even though these forms of motivation are important but maybe are not as good as intrinsic motivation, they can still inspire students to work hard."

Recent reviews point to an exciting resurgence of research on motivation of learning English by using sense-making techniques (Abakumova and Zorina, 2017). Sense-making techniques in EFL are teaching methods boosting the motivation of learning English through incremental tenets of L2 as an individual value. A foreign language should be personally significant to set goals, choose language improvement strategies, and exercise self-esteem and self-control (Stakanova, 2017). All in all, sense-making techniques in learning English are such active methods as projects, debates, role-plays, creative writings/ essays, academic controversy, thought-provoking assignments and language portfolio. It seems appropriate to say that sense-making techniques have plethora of advantages:

- they allow students to combine traditional classroom tuition with the cross-curricular skills increasing students' intrinsic motivation

- develop a semantic sphere of students (Stakanova et al, 2013);

- rapport exists in the classroom activities;

- sense-making techniques improve discourse competence;

- promote motivationally oriented teaching.

Emphasizing methods of teaching EFL we compiled the classification of sense-making techniques adapted from the classification of sense-making techniques in educational sphere by Abakumova I.V. et al. (2017). 
Table 1. Sense-making techniques in EFL meaning-centered instruction

\begin{tabular}{|c|c|c|c|}
\hline No & $\begin{array}{l}\text { Type of } \\
\text { sense-making } \\
\text { techniques }\end{array}$ & Example & Practical Use \\
\hline 1 & $\begin{array}{l}\text { Sense-making } \\
\text { technique of } \\
\text { academic } \\
\text { controversy }\end{array}$ & $\begin{array}{l}\text { Critical thinking, } \\
\text { generalization, } \\
\text { rhetorical skill, } \\
\text { principles of making } \\
\text { arguments }\end{array}$ & $\begin{array}{l}\text { Debates, } \\
\text { discussions }\end{array}$ \\
\hline 2 & $\begin{array}{l}\text { Sense-making } \\
\text { technique of a } \\
\text { dialogue }\end{array}$ & $\begin{array}{l}\text { External, internal, } \\
\text { cultural types of a } \\
\text { dialogue }\end{array}$ & $\begin{array}{l}\text { "Open-ended } \\
\text { questions" "Find } \\
\text { the Riddle Word" }\end{array}$ \\
\hline 3 & Gamification & $\begin{array}{l}\text { Role-playing, } \\
\text { imitation, game- } \\
\text { travel, theatrical } \\
\text { plays. }\end{array}$ & $\begin{array}{l}\text { Poetry Quiz, role } \\
\text { plays with } \\
\text { discussion, living } \\
\text { through situations }\end{array}$ \\
\hline 4 & $\begin{array}{l}\text { Sense-making } \\
\text { technique of } \\
\text { self- } \\
\text { expression }\end{array}$ & $\begin{array}{l}\text { Reflection, existential } \\
\text { choice, } \\
\text { personalization }\end{array}$ & $\begin{array}{l}\text { Reflection of } \\
\text { mood and } \\
\text { emotional state, } \\
\text { rumination of } \\
\text { activity and } \\
\text { educational } \\
\text { material }\end{array}$ \\
\hline 5 & $\begin{array}{l}\text { Sense-making } \\
\text { technique of } \\
\text { group } \\
\text { dynamics }\end{array}$ & $\begin{array}{l}\text { Building a sense of } \\
\text { belonging, trust and } \\
\text { acceptance in the } \\
\text { EFL classroom. This } \\
\text { technique enables } \\
\text { students to } \\
\text { experience a diversity } \\
\text { of personalities and } \\
\text { perspectives. }\end{array}$ & $\begin{array}{l}\text { Activities "Fun } \\
\text { facts about Our } \\
\text { Class", "My } \\
\text { Unforgettable } \\
\text { Story". } \\
\text { Book Clubs }\end{array}$ \\
\hline 6 & $\begin{array}{l}\text { Sense-making } \\
\text { techniques of } \\
\text { creativity }\end{array}$ & $\begin{array}{l}\text { Art techniques, } \\
\text { creative works, } \\
\text { projects, } \\
\text { presentations }\end{array}$ & $\begin{array}{l}\text { Pictures to the } \\
\text { topic under study, } \\
\text { cartoons on the } \\
\text { issues under } \\
\text { consideration, } \\
\text { drawing up } \\
\text { diagrams, etc. }\end{array}$ \\
\hline 7 & $\begin{array}{l}\text { Sense-making } \\
\text { techniques of } \\
\text { problem- } \\
\text { solving }\end{array}$ & $\begin{array}{l}\text { Problem-solving } \\
\text { assignments }\end{array}$ & $\begin{array}{l}\text { Article for the } \\
\text { Newspaper }\end{array}$ \\
\hline
\end{tabular}

\section{MATERIALS AND METHODS}

The current research presented the descriptive analysis of the finding. This study explored sense-making techniques of teaching and learning English as a tool of breaking down the language barriers and increasing motivation. In the empirical part of the study the main concern was finding out the reasons of difficulties of learning L2 and barriers to fluent EFL communication. Consistent to the present finding, the study supported the hypothesis that sense-making techniques can augment motivation to learn a target language.

In the light of the research conducted it's believed that sense-making techniques influence positively the academic performance and L2 acquisition. The participants of the research were 85 students of Southern Federal University, Russia: 35 tertiary level Russian students of different majors and 50 MA psychology students. The subjects had been studying Eng- lish for 10-12 years as a compulsory subject. Tertiary students had Pre-Intermediate level of L2 and MA students had Intermediate/UpperIntermediate level.

Two groups of the experiments were formed: a control group (tertiary level students) who studied English using standardized and traditional methods of instruction, and an experimental group (MA students) where we implemented sense-making techniques in the English classes.

The research involved administering questionnaire BALLI (Beliefs about Language Learning Inventory) by Horwitz (1985). The questionnaire includes 31 points to evaluate students' stance in five global domains: 1) impediments in EFL learning 2) the English language aptitude, 3) the core of language learning, 4) discourse methods, and 5) linguistic prospects.

For revelation of motivation profile, the questionnaire by Douglas Brown "Strategies of Learning English" (Brown, 2007), and the questionnaire by Michael Harris (Harris and McCann, 1994) were used. The participants were asked to estimate their motivational strategies of learning EFL. Further on, the subjects were asked to fill in the questionnaire "Sense-creative strategies in learning a foreign language" (Stakanova, 2017). The questionnaire included 3 units consisting of various statements: 1) metacognitive strategy (developing ability to manage time, self-study, and learner autonomy); 2) cognitive strategy (developing the skills of using the effective learning methods); 3) socio-affective strategy (developing social skills, a student-teacher interaction). The subjects needed to specify what actions they often do (2 points), seldom (1 point), never (0 points).

\section{RESULTS}

The problem is subject to conscious scrutiny and indicated the following results. The issues of motivation and breaking down language barriers have always been a thorny problem and ones that have culminated in numerous heated discussions.

By observing the two groups of trainees, we were able to point out that with the help of all above-mentioned sense-making methods, such as debates, project work, problemsolving tasks, critical thinking tasks, questionnaires it was possible to observe the students' vocational aspirations, self-assessment and learner autonomy. Project work, drama, dis- 
cussions, and debates are very productive as they activate all the necessary communicative skills, all the aspects of communicative competence, thereby bringing real life into lessons. Sense-making techniques teach trainees to value one another as equals, regardless of their abilities and encourage them to be tolerant to each other. It gives every student a feeling of achievement, motivates and challenges them, and develops their communicative skills (Pavlova, 2008).

As for the criterion of meta-cognitive strategies, the same holds true to the control group of respondents, and the experimental one who showed almost equal results. We have found this familiarity to be a major benefit. However, students in the control group mainly concentrated on homework without any creative activities. Cognitive strategies of the subjects in the control group were linked with psychological concepts such as memory, thinking. They could hardly assess the personal experience with the English language, since this experience was necessary to explicate, i.e., to transfer into the verbal form. Participants in the control group were grammar conscious. The problems encountered by students in the control group in socio-affective strategy were the fear of making a mistake and misunderstanding. The subjects manifested self-control to eliminate the language barrier.

As for meta-cognitive strategies, the participants of the experimental group cast their opinion in favor of learner autonomy. They expressed their opinion with evidence about high level of self-regulation, independent fulfilling the assignments.

In cognitive strategies the subjects of the experimental group displayed the ability of honing oral communication. They indicated the interplay of affect, cognition, and language.

According to socio-affective strategy, the students of the experimental group confessed that they embarked on the study of an L2 with perseverance once the learners were not motivated by shortcomings or failure.

In the experiment to define motivation using questionnaires we found out that students had manifold motivations. For example, the most common item was integrative approach (socializing with native speakers), intrinsic (importance of being a fluent speaker in L2), and extrinsic motivation (to obtain a prestigious job). Sense-making techniques can enhance intrinsic motivation and can keep learners engaged.

The data captured during sense-making and motivational questionnaires revealed that $80 \%$ subjects of control group and $50 \%$ respondents of experimental group found the English language difficult to learn. The unwillingness of learners to develop language skills, in majority cases, failed to go unnoticed. Among all the motivational factors, using sense-making techniques had an important bearing on the EFL learning.

In language aptitude, $75 \%$ of respondents adhered to the idea that females were better at language learning than males. The central grounding factor in the language aptitude and awareness is memory. This idea is applicable to creating meaningful context for memorizing material.

Ruminating on the issue of stumbling blocks to language barriers that prevent Russian EFL learners from speaking English is firstly, lack of English language environment outside the classroom; secondly, aims should be encapsulated in the interactions between sense-making context and motivation. Learning English should be a personal need for a student. In the long run, it will be the stepping stone to success.

The analysis of academic performance indicators demonstrated a higher degree of schooling among students who attended classes based on sense-making paradigm, than did learners from the control group who studied on a traditional curriculum.

\section{DISCUSSIONS}

The present research was an attempt to investigate the influence of sense-making techniques on the L2 acquisition and increasing motivation, hence breaking down barriers to speaking English as a target language. The problem is subject to conscious scrutiny, so we have come to the following conclusions.

1. New emphasis on sense-making techniques in the meaning-centered instruction is encapsulated in developing the semantic sphere of students and supports motivation of learning the target language.

2. Sense-making context is a system of teaching methods aimed at meeting individual values of students in learning EFL. This paradigm is the conceptual approach to education fostering effort and resilience to failure in students.

3. Meaning-centered instruction provides the development of EFL learners, allows forming the skills of learner autonomy.

4. Sense-making context initiates sense- 
creative potential of students, makes them set goals, learn the English language, improve one's knowledge, and exercise self-esteem and self-control.

5. To increase the learners' interest in speaking skill of L2, motivation plays a vital role in this regard. A learner can be motivated in different ways.

6 . Results obtained in the study indicated that those L2 learners who studied in the sense-making context are more successful in such course. This is in compliance with the position of humanistic approaches to language teaching.

\section{CONCLUSIONS}

The outcome of the longitudinal analysis has some significant implications. In the light of information gathered it's believed that sense-making techniques take off in a big way in the teaching practice. The issue of raising motivation should be carried out in the teacher-learner interactions.

In conclusion, this study has an important bearing on a number of issues in the current theories and approaches. Aims were specific and implementation indicators were established. This ensures that the goals were taking place in practice and could be open to redefinition because of practice.

The fulfillment of these objectives enables teachers to shift from the traditional language approaches to sense-making context. Using the sense-making techniques, we change the priorities and utilize the approach, the essence of which is to put the student in the conditions when he/she feels the inner need to acquire knowledge. advantages:

Sense-making techniques have a host of

- activate the process of fulfilling comprehension exercises;

- develop self-regulation;

- take the English language as a means of self-development;

- attach students to other cultures, therefore forming a universal consciousness;

- create a favorable basis for mastering a foreign language, as well as for lifelong independent language learning at later stages;

- enhance general educational skills and learner autonomy by expanding their scope in the process of mastering a foreign language.

\section{ACKNOWLEDGEMENTS}

The author expresses her gratitude to Southern Federal University that made this project possible.

\section{Conflict of interests}

The author declares no conflict of interest.

\section{REFERENCES}

Abakumova, I. V., \& Zorina, E. S. (2017). Sense-making Techniques in Educational Process and their Impact on the Personal Characteristics of students. International Journal of Cognitive Research in Science, Engineering and Education, 5(2). https://doi.org/10.5937/IJCRSEE1702041A

Abakumova, I.V. (2003). Education and Sense: Sensecreation in the academic process. Rostov-onDon, Russia: Southern Federal University.

Alam, M., Alam, M., \& Farzana, S. (2018). Taking Lead in L2 Speaking Skill through Teachers' Motivation: A Retrospection of Private Universities in Bangladesh. Australasian Journal of Business, Social Science and Information Technology, 4(3), 94-102. Retrieved from http://www.ajbssit. net.au/index.php/AJBSSIT/article/view/70/57

Amirian, S. M. R., \& Komesh, N. (2018). A study on the Relationship between EFL Learners' Nationality and Language Learning Motivation. International Journal of Applied Linguistics and English Literature, 7(2), 26-32. http://dx.doi. org/10.7575/aiac.ijalel.v.7n.2p.26

Baker, J. Westrup. H. (2003). Essential Speaking Skills: A handbook for English Language Teachers.

Baran-Łucarz, M. (2013). Foreign Language Pronunciation and Listening Anxiety: A Preliminary Study. Language in Cognition and Affect (pp. 255-274). Springer, Berlin, Heidelberg. https:// doi.org/10.1007/978-3-642-35305-5_15

Beere, J. (2016). The Perfect Lesson (3rd e⿳亠口冋.). UK: Independent Thinking Press.

Brown, D. (2007). Teaching by Principles. London: Pearson Longman.

Dörnyei, Z., \& Csizér, K. (1998). Ten commandments for motivating language learners: Results of an empirical study. Language teaching research, 2(3), 223-229. https://doi. org/10.1177/136216889800200303

Dörnyei, Z., (2001). Motivational Strategies in the Language Classroom. Cambridge, UK: Cambridge University Press. https://doi.org/10.1017/ CBO9780511667343

Fengying, M. (2003). Motivating Students by Modifying Evaluation Methods. English Teaching Forum, 41(1), 38-41. https://americanenglish. state.gov/resources/english-teaching-forum2003-volume-41-number-1

Gardner, R. C. (1985). Social psychology and second language learning: The role of attitudes and motivation. Arnold.

Gardner, R. C., \& MacIntyre, P. D. (1991). An instrumental motivation in language study: Who says it isn't effective? Studies in second language acquisi-tion, 13(1), 57-72. https://doi.org/10.1017/ 
Elena Stakanova (2018) - Breaking down barriers to effective EFL communication: a look at sense-making techniques

International Journal of Cognitive Research in Science, Engineering and Education (IJCRSEE), 6(3), 29-34

S0272263100009724

Gracheva, M. (2015). The Arts in the World of Academia. English, 9, 56-57. http://eng.1september. $\mathrm{ru} / \mathrm{index}$. php?year $=2015 \&$ num $=09$

Harris, M., \& McCann, P. (1994). Assessment. Oxford, UK: Macmillan.

Harmer, J. (1983). The practice of English language teaching. Longman, 1560 Broadway, New York, NY 10036. https://eric.ed.gov/?id=ED240864

Horwitz, E. (1985). Using student beliefs about language learning and teaching in the foreign language methods course. Foreign Language Annals, 18(4), 333-340. https://doi. org/10.1111/j.1944-9720.1985.tb01811.x

Krieger, D. (2005). Teaching ESL versus EFL: Principles and practices. English Teaching Forum, 43(2), 8-16. https://americanenglish.state.gov/ resources/english-teaching-forum-2005-volume-43-number-2\#chId-608

Pavlova, L. (2008). Challenges and rewards of teaching a teenager. English, 19, 3. https://eng.1 september. $\mathrm{ru} /$ index.php?year $=2008 \&$ num $=19$

Stakanova, E. V., Dzyuba, E. A., \& Tolstikhina, E. V. (2013). Teaching EFL Students in Sense-Creation Context of Learning. Procedia-Social and Behavioral Sciences, 86, 494-497. https://doi. org/10.1016/j.sbspro.2013.08.603

Stakanova, E. (2017). Sense-creative context as a factor of learner autonomy in a foreign language acquisition. People: International Journal of Social Sciences, 3(3). 675-683. https://grdspublishing. org/index.php/people/article/view/939

Stepichev, P. (2009). Teaching Creativity through English. English, 14, 5. https://eng.1september.ru/ index.php?year $=2009 \&$ num $=14$ 